\title{
The Crucial Role of c-Src Tyrosine Kinase in Bone Metabolism
}

\author{
Barbara Peruzzi ${ }^{1}$, Nadia Rucci ${ }^{2}$ and Anna Teti ${ }^{2}$ \\ ${ }^{1}$ Regenerative Medicine Unit, Ospedale Pediatrico Bambino Gesù. Rome \\ ${ }^{2}$ Department of Experimental Medicine, University of L'Aquila
}

Italy

\section{Introduction}

c-Src belongs to the SRC Family of non receptor tyrosine kinases (SFKs), which includes at least ten members (Lyn, Fyn, Lck, Hck, Fgr, Blk, Yrk, Gfr, Yes and c-Src) sharing high homology in their domain structure (Brown \& Cooper, 1996).

Due to its proto-oncogene nature, c-Src is the SFK most frequently associated with malignancy (Yeatman, 2004). Over 100 years ago, Peyton Rous observed that injection of cell-free extracts from tumours grown in chickens caused the development of the same type of tumour in host animals. This observation prompted the hypothesis that a filterable agent was the cause of the tumour (Rous, 1911a, 1911b). In support of this notion, in 1955 Rubin showed that the Rous'filterable agent was a virus, called Rous Sarcoma Virus (RSV), which was found to play a direct role in inducing cell malignancy (Rubin, 1955). In the '60s and '70s, the tools of modern molecular biology provided the genetic definition of v-Src, a viral oncogene included within the RSV genome. v-Src was observed not to be required for virus replication but to be the causative agent of cancer (Martin, 1970; Duesberg \& Vogt, 1970). Shortly thereafter, it was shown that v-Src had a counterpart in eukaryotic cells, named c-Src (Takeda and Hanafusa, 1983). c-Src is involved in many physiological functions of the cells. It carries a regulatory domain lacking in v-Src (Fig. 1), therefore, its activity is under tight molecular control. c-Src was the first of several proto-oncogenes discovered in the vertebrate genome and, in 1989, this discovery earned Bishop and Varmus the Nobel Prize in Physiology or Medicine, for the description of "the cellular origin of retroviral oncogenes".

In 1977, Brugge and Erikson immunoprecipitated a 60-kDa phosphoprotein from RSVtransformed fibroblasts. The protein was called pp60v-src, but it is now usually referred as vSrc. Both v- and c-Src have tyrosine kinase activity (Collett et al, 1978; Oppermann et al, 1979). c-Src also autophosphorylates itself at tyrosine residues (Hunter \& Sefton, 1980), and is the prototype of a large family of kinases that we now know are involved in the regulation of cell growth and differentiation.

v-Src lacks the C-terminal domain that in c-Src has a negative regulatory role on its tyrosine kinase activity. Consequently, v-Src shows constitutive activity and transforming ability (Jove \& Hanafusa, 1987). In addition, v-Src contains point mutations throughout its coding 
region that probably contribute to the high intrinsic activity and transforming potential of the protein.

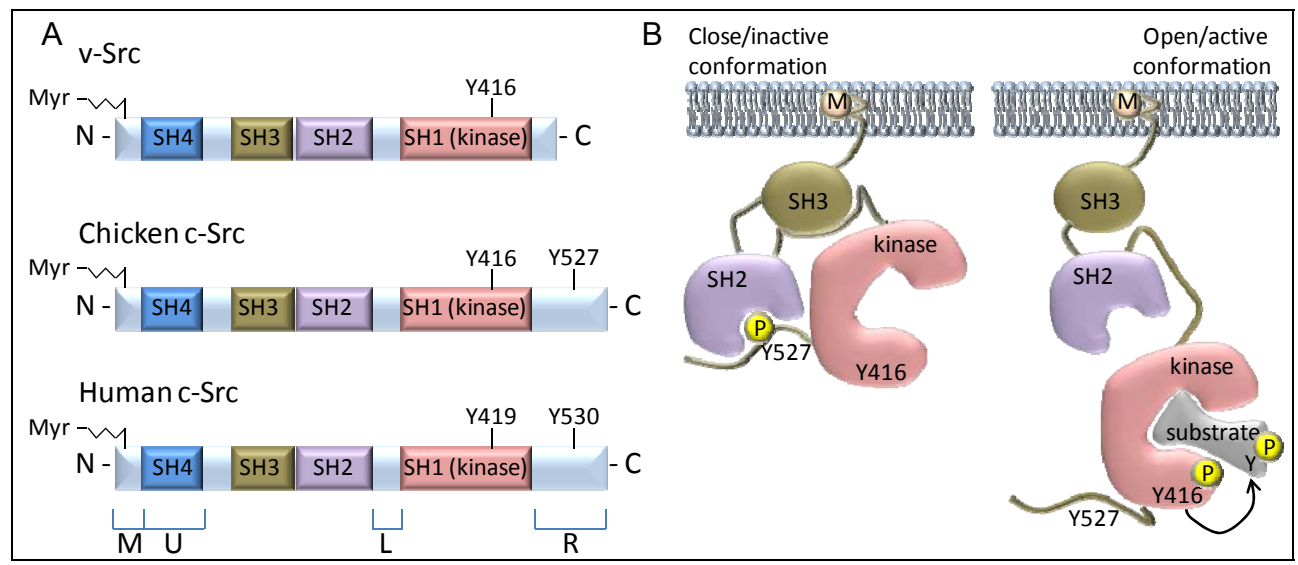

Fig. 1. Structure and activation of Src proteins

A) Comparison of protein structure of viral (v-)Src, chicken and human cellular (c-)Src, with indication of Src homology (SH) and membrane-binding (M), unique (U), linker (L) and regulatory (R) domains. (B) Representation of inactive (left) and active (right) conformation of chicken c-Src.

Aberrant activation of c-Src results in a wide variety of cellular phenotypic changes, including morphological transformation and acquisition of anchorage and growth-factor independence, that are implicated in the development, maintenance, progression, and metastatic spread of several human cancers, such as prostate, lung, breast, and colorectal carcinomas (Irby \& Yeatman, 2000). Indeed, a number of human malignancies display increased c-Src expression and activation, confirming its involvement in oncogenesis (Alvarez et al, 2006).

c-Src is ubiquitous and physiologically expressed at high levels in a variety of cell types, including neurons and platelets (Brown \& Cooper, 1996). Nonetheless, the very first mouse model of c-Src deficiency (Soriano, 1991) showed an unexpected prominent bone phenotype characterized by increased bone mass and lack of bone resorption, unveiling a previously unrecognized role of c-Src in bone cells (Boyce et al, 1992; Marzia et al, 2000).

In this review, we will describe the structure and function of c-Src and will highlight its crucial physiological and pathogenetic role in bone metabolism.

\section{2. c-Src structure, activation and function}

\section{1 c-Src structure}

c-Src shares with the other SFK members a conserved domain structure consisting of four consecutive Src Homology ( $\mathrm{SH}$ ) domains (Fig. 1A). The N-terminal segment includes the SH4 domain, as well as an "unique" domain of 50-70 residues that display the greatest divergence among the family members (Koegl et al., 1994 ; Resh, 1999). The SH3, SH2 and SH1 (catalytic) domains follow in order in the polypeptide chain. There is also a short, C- 
terminal "tail" which includes a hallmark of Src kinases, that is an autoinhibitory phosphorylation site [Tyrosine (Tyr) 527 in chicken, Tyr 530 in human] (Cooper \& King, 1986). This tail is not present in the v-Src isoform (Fig.1A).

The SH4 domain is a 15-amino acid sequence whose myristoylation allows binding of SFK members to the inner surface of the plasma membrane. The unique domain has been proposed to be important for mediating interactions with receptors or proteins that are specific for each family member. Serine and threonine phosphorylation sites have also been identified in the unique domains of c-Src and Lck (Winkler et al, 1993).

SH3 and SH2 are protein-binding domains widely present in other molecules, such as lipid kinases, protein and lipid phosphatases, cytoskeletal proteins, adaptor molecules and transcription factors (Mayer \& Baltimore, 1993). The SH3 domain consists of small, $\beta$-barrel modules and is important for intra- as well as inter-molecular interactions, regulating c-Src catalytic activity, localization and recruitment of substrates. Proline-rich sequences in target molecules mediate the interactions with SH3 (Ren et al, 1993). The other domain regulating c-Src interaction with proteins is $\mathrm{SH} 2$, which preferentially binds to polypeptide segments containing a phosphotyrosine (Mayer et al, 1991; Pawson, 1995).

The catalytic domain (SH1) is the most conserved domain in all tyrosine kinases. It contains an ATP-binding pocket and the tyrosine-specific protein kinase activity. As it will be described in the next paragraph, the first step of c-Src activation is the autophosphorylation of Tyr416 (in chicken, Tyr419 in human), while phosphorylation of Tyr527 by c-Src kinase (CSK) and CSK homologous kinase (CHK) results in its inhibition (Kmiecik \& Shalloway, 1987; Cartwright et al, 1987; Piwnica-Worms et al, 1987; Okada \& Nakagawa, 1989).

\section{2 c-Src activation}

c-Src is normally maintained in an inactive or "closed" conformation, where the SH2 domain is engaged with the phosphorylated Tyr527, the SH3 domain binds the SH2-kinase linker sequence and the Tyr416 is dephosphorylated. Dephosphorylation of Tyr527 disrupts its intramolecular interaction with the $\mathrm{SH} 2$ domain and this open conformational state allows autophosphorylation of Tyr416, resulting in c-Src activation (Fig. 1B) (Yamaguchi \& Hendrickson, 1996).

Phosphorylation of Tyr527 can be removed by several protein phosphatases that function as activators of c-Src, such as protein tyrosine phosphatase-a (PTPa) (Zheng et al, 1992), PTP1, SH2-containing phosphatase 1 (SHP1) and SHP2 (Jung \& Kim, 2002). The most direct evidence for a role of c-Src activation in cancer among these phosphatases is for PTP1B, which is present at high levels in breast cancer cell lines (Jung \& Kim, 2002). In addition, the direct binding of focal-adhesion kinase (FAK) (Schaller et al, 1994) or its molecular partner CRK-associated substrate (CAS, also known as p130CAS) to the SH2 and the $\mathrm{SH} 3$ domains of c-Src also results in the open, active configuration of c-Src, since the intramolecular interactions that maintain the closed configuration are displaced (Thomas et al, 1998).

\section{3 c-Src functions}

c-Src plays a key role in regulating the assembly and disassembly of cell-cell (adherens junctions) and cell-matrix (focal adhesions) adhesion (Yeatman, 2004) (Fig.2). Adherens 
junctions are maintained by homotypic interactions between E-cadherin molecules present on neighboring cells, and loss of E-cadherin is a key event in the epithelial-to-mesenchymal transition of cancer cells. It has been shown that increased c-Src signalling correlates with decreased E-cadherin expression and decreased cell-cell adhesion (Irby and Yeatman, 2002; Nam et al, 2002). Moreover, constitutively active c-Src can phosphorylate the cadherins, resulting in loss of the cadherin-catenin complex function, thereby promoting cell invasiveness (Irby \& Yeatman, 2002; Behrens et al, 1989) (Fig.2).

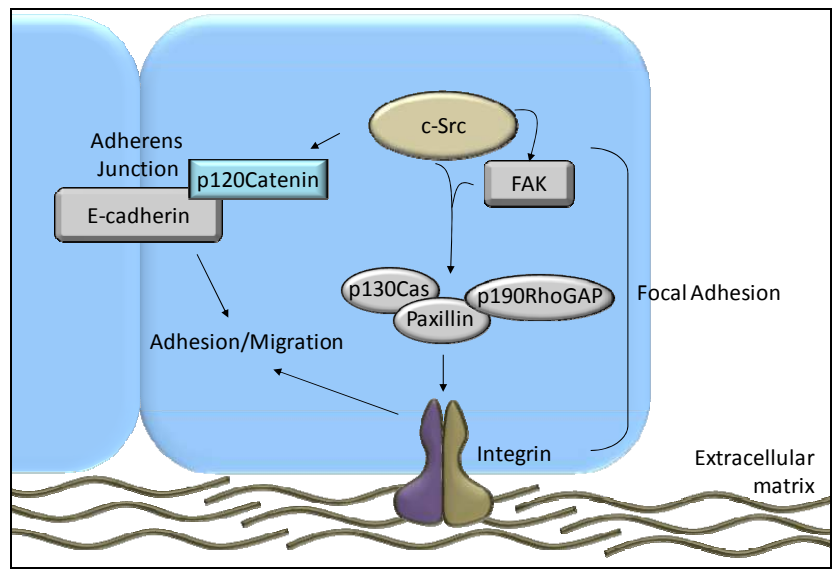

Fig. 2. c-Src involvement in cell adhesion signals.

Molecular interactions among c-Src and the components of both adherens junction and focal adhesion structure.

At the cell periphery, activated c-Src forms complexes with FAK, which in turn interacts with a multitude of substrates, including CAS, paxillin, and p190RhoGAP, that play critical roles in promoting actin remodelling and cell migration (Fig. 2) (Guarino, 2010; Playford \& Schaller, 2004). In cancer, deregulated focal adhesion signalling has been implicated in increased invasion and metastasis, and decreased patient survival (McLean et al, 2005). c-Src can also be activated downstream of tyrosine kinase growth factor receptors, such as epidermal growth factor (EGF) (Tice et al, 1999), platelet-derived growth factor (PDGF) (De Mali et al, 1999; Bowman et al, 2001), insulin-like growth factor (IGF)-1 (Arbet-Engels et al, 1999), fibroblast growth factor (FGF) (Landgren et al, 1995), colony-stimulating factor (CSF)1 (Courtneidge et al, 1993) and hepatocyte growth factor (HGF) receptors (Mao et al, 1997) (Fig. 3). Ligand binding to receptor tyrosine kinases leads to receptor dimerization, kinase activation, and autophosphorylation of tyrosine residues. These phosphorylated tyrosines then serve as docking sites for the $\mathrm{SH} 2$ domains of several signalling molecules, including c-Src (van der Geer et al, 1994). For instance, the EGF receptor can bind to c-Src and phosphorylate tyrosine sites on its C-terminal loop. Conversely, c-Src can directly bind to the EGF receptor and phosphorylate the Y845 residue, resulting in increased Ras/ERK/MAPK activity and enhanced cell mitogenesis and transformation (Biscardi et al, 2000).

c-Src has also been implicated in signalling activated by integrins and G-protein coupled receptors (GPCRs). Indeed, clustering of integrins can lead to downstream signalling 
pathways inducing activation of c-Src, FAK, Abl, and Syk (Miyamoto et al, 1995, Schlaepfer \& Hunter, 1998). There is an increasing body of evidence for synergy between receptor tyrosine kinases and integrins, demonstrated by an increase in MAPK activation in response to various growth factors if integrins are preclustered (Miyamoto et al, 1996). The crosstalk between these pathways could be mediated by a common signalling molecule, including cSrc. A FAK-independent signalling pathway from integrins has also been described, in which caveolins act as adaptors, linking integrins and c-Src family kinases. Indeed, Wei et al. (1999) showed that caveolin is important for the association between $\beta 1$ integrin and c-Src, and disruption of this interaction affected focal adhesions. On the other hand, c-Src can suppress the integrins attached to the extracellular matrix via phosphorylation of integrin subunits (Sakai et al, 2001; Datta et al, 2002). c-Src can also interrupt Rho-A function, which has an important role in actin filament assembly and stabilization of focal adhesions (Arthur \& Burridge, 2001). c-Src activates FAK, Ras and phosphatidylinositol phosphate kinase, which indirectly affect integrin-actin cytoskeleton assembly (Brunton et al, 2004).

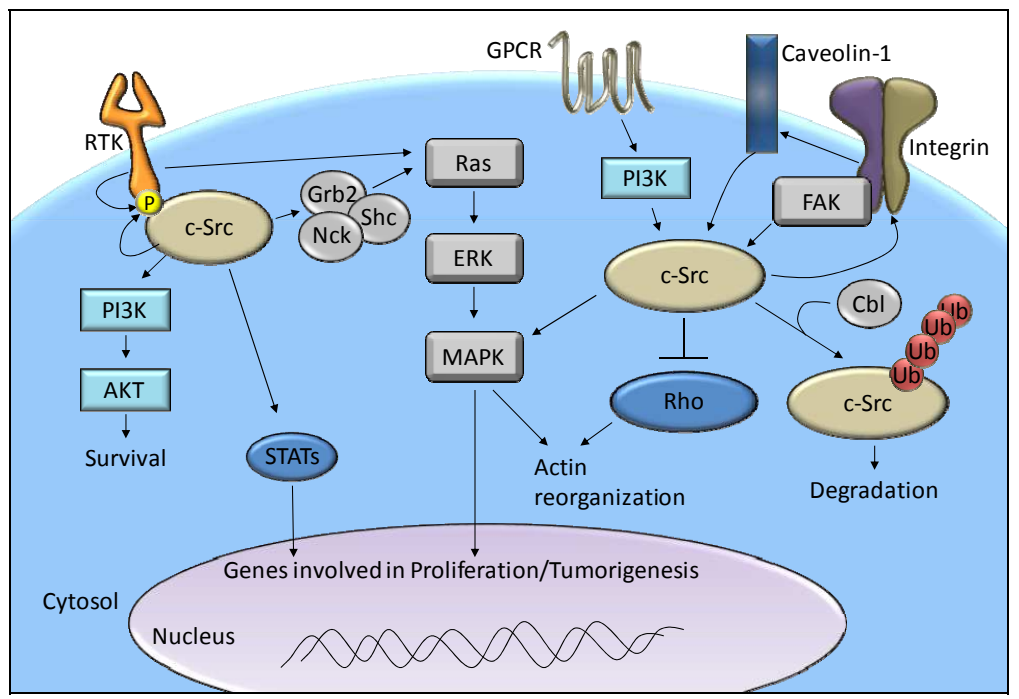

Fig. 3. c-Src-activating signals.

Extracellular signals involving Receptor Tyrosine Kinases (RTK), or G-Protein Coupled Receptors (GPCR) or integrins are shown to activate c-Src and its downstream pathways.

The localization of c-Src at the membrane-cytoskeletal interface in focal adhesions, lamellipodia and filopodia seems to be regulated by the small G-proteins RhoA, Rac1 and CdC42 (Timpson et al, 2001). The Cbl ubiquitin ligase has been shown to be important in suppressing v-Src transformation through ubiquitin-dependent protein degradation (Kim et al, 2004). Recent evidence indicates that the ubiquitin-proteasome pathway is deregulated in cancer cells, which might allow c-Src activation (Kamei et al, 2000).

Finally, there is also evidence that c-Src is activated through nitric-oxide signalling (Akhand et al, 1999) in mechanisms mainly implicated in cellular adhesion and motility (Gianni et al, 2010; Giannoni et al, 2005). 


\section{3. c-Src in the bone metabolism}

Understanding the physiological role of SFKs has been aided by the advent of gene targeting and embryonic stem cell technology in the mouse. Targeted disruptions of all known mammalian SFK genes have been obtained in mice, with their phenotypes ranging from no overt defects to very distinct abnormalities in specific cell types and tissues. As stated above, the first SFK member to be disrupted was c-Src (Soriano et al, 1991). Although c-Src is ubiquitously expressed, mice lacking the src gene presented with overt alterations only in the bone tissue, suggesting a crucial role of this tyrosine kinase in the bone microenvironment that cannot be replaced by other SFK members, as probably occurs in the rest of the body.

The main phenotype associated with c-Src deletion is osteopetrosis, a bone remodelling disease in which excess of bone accumulates as a result of defective osteoclast bone resorption (Soriano et al, 1991). This mutation manifests itself by the failure of incisors to erupt, and the mutants have a much reduced survival rate after weaning. However, animals maintained on a soft food diet have been found to survive for at least a year and, on rare occasions, can breed, although some alterations in reproduction have been documented (Roby et al, 2005). In contrast with a general concept of c-Src involvement in cell proliferation, a detailed analysis of the bone phenotype of c-Src knock-out (KO) mice revealed the crucial role of the tyrosine kinase in regulating osteoclast activity, rather than formation and proliferation (Soriano et al, 1991). As discussed in more detail below, substantial evidence has been already provided in identifying c-Src as a key player in the correct cytoskeletal rearrangement necessary for bone resorption. Further studies pointed out the role of c-Src in bone metabolism, thus showing that the deletion of Src expression also enhances the differentiation and the function of osteoblasts, the cells of the bone tissue having osteogenic function, with a consequent further increase of bone mass (Marzia et al, 2000). Therefore, in this section we will introduce the bone cells and discuss in detail the multiple roles that c-Src exerts in the bone microenvironment.

\section{$3.1 \mathrm{c}-\mathrm{Src}$ regulation of osteoclast behaviour}

Osteoclasts are multinucleated cells, originating from the myeloid tissue from which the mononuclear osteoclast progenitors arise and fuse into polykaria when their maturation is completed (Baron \& Horne, 2005). They are terminally differentiated cells that resorb the mineralized matrix during physiological and pathological bone turnover by a peculiar extracellular mechanism involving specific domains of the plasma membrane. Indeed, during the bone resorbing process, the osteoclast is markedly polarized, in order to create three morphologically distinct areas of the plasma membrane: the basolateral membrane, which is not in contact with the bone; the tight sealing zone, which is closely apposed to the bone surface; and the ruffled border, a highly convoluted membrane that faces the resorbing surface (Baron \& Horne, 2005).

The characterization of the phenotype of the c-Src KO mouse revealed that the most critical role of c-Src is related to osteoclast function rather than differentiation, since the number of osteoclasts in bones of c-Src KO mice is more than twice that in normal mice (Boyce et al, 1992). While osteoclasts also express other c-Src family kinases (Lowell et al, 1996), the deletion of any one of the genes encoding Fyn, Yes, Hck, and Fgr fails to produce 
osteopetrosis (Stein et al, 1994). Moreover, re-expression of c-Src in c-Src KO osteoclasts restores in vitro the bone-resorbing activity (Miyazaki et al, 2004), implying that c-Src performs some specific functions in osteoclasts that cannot be compensated by these other SFKs. A possible exception is Hck, since its expression is upregulated in c-Src KO osteoclasts and c-Src $\mathrm{KO} / \mathrm{Hck} \mathrm{KO}$ double-mutant mice are significantly more osteopetrotic than the cSrc KO animals (Lowell et al, 1996). At the cellular level, c-Src KO osteoclasts present with a critical feature, that is the absence of the ruffled border (Boyce et al, 1992), suggesting a c-Src contribution to the regulation of exocytic and/or endocytic vesicle trafficking, as well as to the attachment and motility mediated by the adhesion structures.

Osteoclastic bone resorption involves a series of regulatory phases: migration of osteoclasts to the resorption site, their attachment to the calcified tissue and development of the ruffled border and the clear zone, followed by the secretion of acids and lysosomal enzymes into the space beneath the ruffled border (reviewed in Peruzzi \& Teti, 2011). The formation of the sealing zone is essential for the osteoclastic bone resorption, since it forms a diffusion barrier and permits the directional secretion of lysosomal enzymes into the space beneath the ruffled border. In the ruffled border membrane, the vacuolar-type proton ATPase mediates the transport of protons into the resorption lacunae. Lysosomal enzymes of osteoclasts, such as cathepsin $\mathrm{K}$, and metalloproteinase- 9 are also secreted through this membrane and degrade the organic matrix of bone. To organize these highly polarized cellular structures, osteoclasts must adhere to the bone surface as the initial and essential phase for their activity (Coxon \& Taylor, 2008), which involves the interaction of integrins with the extracellular matrix proteins within the bone. Among several integrins, osteoclasts express very high levels of $\alpha \mathrm{V} \beta 3$ integrin, and lower levels of the collagen/laminin receptor $\alpha 2 \beta 1$ and the vitronectin/fibronectin receptor aV $\beta 1$ (Nakamura et al, 2007; Horton, 1997; Horton \& Rodan, 1996).

Like all members of the $\alpha V$ integrin family, the $\alpha V \beta 3$ receptor recognizes the RGD (Arg-GlyAsp) adhesion motif present in several matrix proteins such as vitronectin, bone sialoprotein II and osteopontin (Rupp \& Little, 2001; Wilder, 2002; Horton, 1997). This interaction induces an integrin conformational change leading to the so-called outside-in signalling, which in turn triggers a number of intracellular events, including changes in cytosolic calcium, protein tyrosine phosphorylation and cytoskeletal remodelling (Duong \& Rodan, 2000; Teitelbaum, 2007; Faccio et al, 2003). The engagement of the matrix by the aV $\beta 3$ integrin in osteoclasts and osteoclast precursors activates the non-receptor tyrosine kinase Pyk2, a member of the FAK family, by a mechanism that involves an increase in cytosolic $\mathrm{Ca}^{2+}$ and the binding of Pyk2 to the cytoplasmic domain of the $\beta$ subunit (Fig.4) (Faccio et al, 2003; Duong \& Rodan, 2000).

Both the capacity of c-Src to bind the aV 33 integrin and the subsequent activation of the kinase are mediated by Pyk2, which mobilizes c-Src to the integrin. $\alpha \mathrm{V} \beta 3$ integrin occupancy induces phosphorylation of Pyk2, which then binds the SH2 domain of c-Src. The proposed association between phosphorylated Pyk2 and c-Src would prevent c-Src-Y527 inactivating phosphorylation, thus relieving auto-inhibition of kinase function.

The signalling downstream of c-Src activation involves tyrosine phosphorylation of a distinct set of proteins, including Pyk2 itself, Cbl, PI3K, paxillin, cortactin, vinculin, talin, tensin, and p130Cas, which are present in the osteoclast adhesion structures, called podosomes (Thomas \& Brugge, 1997; Linder \& Aepfelbacher, 2003; Buccione et al, 2004). 


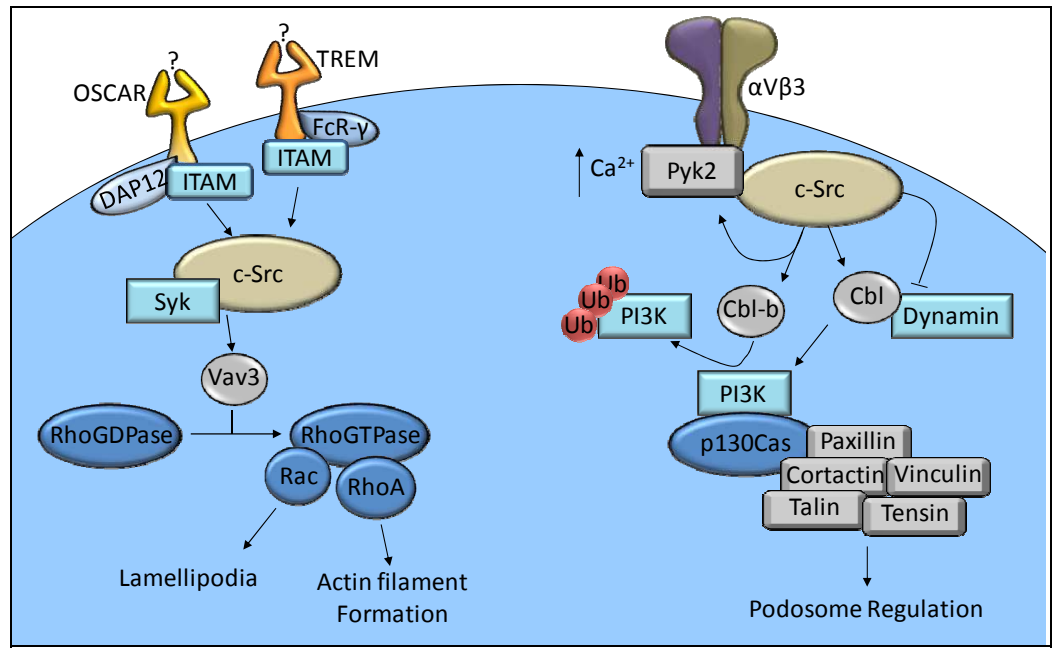

Fig. 4. c-Src involvement in osteoclast function.

Among several pathways regulating osteoclast activity, the cartoon shows c-Src activation and downstream effect depending on receptor signals.

Podosomes, which serve as attachment structures in osteoclasts and other highly motile cells, are more transient and dynamic than focal adhesion plaques (Destaing et al, 2003). As originally described (Marchisio et al, 1984; Marchisio et al, 1987), podosomes are small punctate structures with an F-actin-rich core surrounded by a ring of integrins and certain focal adhesion-associated proteins (e.g., paxillin, talin and vinculin). Cortactin, gelsolin, the actin-regulatory proteins Neuronal Wiskott-Aldrich Syndrome Protein (N-WASP), and Arp2/3 have also been identified in the podosome core (Linder \& Aepfelbacher, 2003; Buccione et al, 2004). In osteoclasts, Src, Cbl, Pyk2, and various actin-associated proteins, including dynamin and filamin, are also associated with podosomes, whose rapid turnover (within minutes) is probably essential for the high mobility of the cells in which they occur (Fig. 4) (Destaing et al, 2003).

Among the substrates of c-Src activity involved in the mechanisms of bone resorption, $\mathrm{Cbl}$ plays a key role in promoting turnover or disassembly of podosomes (Sanjay et al, 2001). Indeed, c-Src, in association with Pyk2, recruits $\mathrm{Cbl}$ through its $\mathrm{SH} 3$ domain and promotes its activation by phosphorylation. Once activated, Cbl recruits PI3K and dynamin to the adhesion complex.

Since $\mathrm{Cbl}$ is an ubiquitin E3 ligase, it has been described to drive the negative feedback that has the potential to promote proteasomal degradation of the integrin-associated Pyk2/cSrc/Cbl complex (Fig. 4) (Yokouchi et al, 2001). Thus, Cbl is crucial in the integrin-mediated "inside-out" signalling, playing a key role in podosome detachment and subsequent disassembly. In this way, the c-Src/Pyk2/Cbl complex forms the basis for the cyclic attachment-detachment of single adhesion sites at the leading edge of lamellipodia in motile cells, and thereby participates in the assembly-disassembly of individual podosomes, ensuring cell adhesion while still allowing cell motility (Sanjay et al, 2001). 
In the integrin-mediated outside-in signalling, also the non-receptor tyrosine kinase Syk plays a pivotal role in osteoclast activity, since it associates with the $\beta 3$ integrin subunit domain in a region close to the c-Src binding site and is activated by c-Src itself, a key event in organizing the cytoskeleton (Zou W et al., 2007). Recently, it has been shown that c-Src and Syk are also involved in the signal downstream the immunoreceptor tyrosine-based activation motif (ITAM)-bearing co-receptors, DAP12 and FCRY (Fig.4). DAP12 and FcRY are associated with the immunoreceptors OSCAR/PIR-A and TREM2/SIRP $\beta 1$, respectively, recently identified on the osteoclast surface (Mócsai et al, 2004). The c-Src-mediated phosphorylation of Syk kinase leads to activation of a number of cytoskeleton-regulating proteins, including the Vav family of guanine nucleotide exchange factor (GEFs). These proteins convert Rho GTPases from their inactive GDP to their active GTP conformation. Among these proteins, Vav3 is expressed in osteoclasts (Faccio et al, 2005), where it is triggered upon matrix-induced Syk activation and regulates RhoGTPase-dependent effect on actin cytoskeleton (Zou et al, 2007). In this context, the small GTPases Rac and Rho exert distinctive effects on osteoclasts. Indeed, Rac stimulation in osteoclast precursors prompts the appearance of lamellipodia, thus forming the migratory front of the cell, while RhoA stimulates actin filament formation which, in osteoclasts, allow organization of the sealing zone (Fig.4) (Fukuda et al, 2005).

The integrin-activated c-Src signalling also functions in other processes necessary for normal osteoclast function, among which adenosine triphosphate (ATP)-dependent events, especially those involved in cell motility, proton secretion, and the maintenance of electrochemical homeostasis (Baron, 1993). Indeed, c-Src promotes the maintenance of energy stores in osteoclasts by phosphorylating cytochrome $c$ oxidase within the mitochondria (Miyazaki et al, 2003), which are very abundant in osteoclasts, consistent with the energy requirements of their activity (Miyazaki et al, 2006).

\section{2 c-Src regulation of osteoblast differentiation}

Osteoblasts are mononucleated cells of mesenchymal origin that synthesize and mineralize the bone matrix during bone accrual and remodelling events. Bone formation involves osteoblast maturation that requires a spectrum of signalling proteins including morphogens, hormones, growth factors, cytokines, matrix proteins, transcription factors, and their coregulatory proteins. They act coordinately to support the temporal expression (i.e., sequential activation, suppression, and modulation) of other genes that represent the phenotypic and functional properties of osteoblasts during the differentiation process from osteoblast precursors (Jiang et al, 2002). Pre-osteoblasts are also responsible of the production of cytokines regulating osteoclastogenesis, that is receptor activator of nuclear factor kappa B ligand (RANKL), osteoprotegerin (OPG) and CSF-1, thereby coupling osteoblast and osteoclast function. Given the osteoblast-mediated regulation of osteoclast differentiation and bone resorption (Rodan \& Martin, 1981; Suda et al, 1997) and the bone phenotype resulted by c-Src distruption (Soriano et al, 1991), several studies aimed at investigating the involvement of osteoblasts in c-Src KO phenotype have been performed. In 1993, Lowe et al. demonstrated that osteoblasts derived from these mice successfully contributed to normal osteoclast differentiation and showed unremarkable morphological features relative to wild-type (WT) mice, suggesting that the inherited defect is independent of the bone marrow microenvironment (Lowe et al, 1993). The first evidence of an osteoblast involvement in c-Src KO mouse bone phenotype derived from Marzia and coworkers, who 
performed a detailed molecular analysis of the c-Src null osteoblasts (Marzia et al, 2000). This study clearly demonstrated that a decreased c-Src activity is responsible of enhanced osteoblast differentiation and in vivo bone formation, thereby highlighting the role of c-Src in maintaining osteoblasts in a poorly differentiated status.

Bone formation requires transcriptional mechanisms for sequential induction and repression of genes that support progressive osteoblast phenotype development. The Runx transcription factors and their co-regulators control cell differentiation and lineage commitment (Westendorf \& Hiebert, 1999) by influencing the functional architecture of target gene promoters (Stein et al, 2000). Runx proteins are directed to subnuclear domains through the Cterminal nuclear matrix-targeting signal (NMTS) and interact with the DNA through the Nterminal runt homology domain (Zaidi et al, 2001). The Runx2 family member is essential for osteoblast maturation in vivo and its alteration is associated with the cleidocranial dysplasia (Komori et al, 1997). Runx2 is a target of several extracellular signals that regulate skeletal formation and homeostasis. The C-terminus of Runx2, which includes the NMTS, interacts with proteins involved in the transforming growth factor $\beta /$ bone morphogenetic proteins (TGF $\beta / B M P s)$ (i.e., Smads), the transducin-like enhancer (TLE)/groucho and the c-Src/Yes tyrosine kinase (e.g., the Yes-associated protein, YAP) signalling pathways (Hanai et al, 1999; Yagi et al, 1999). Indeed, in response to c-Src/Yes signalling, YAP is phosphorylated and recruited by Runx2 to subnuclear sites of Runx2 target genes, resulting in their repression (Fig.5). Thus, c-Src controls osteoblast differentiation by regulation of Runx2-YAP interaction.

Another mechanism by which c-Src regulates osteoblast differentiation involves estrogens, which are known to control a variety of tissues, including the bone (Hall et al, 2001). Indeed, estrogen deficiency leads to accelerated bone loss which is the primary cause of postmenopausal osteoporosis (Manolagas et al, 2002). The estrogen receptors (ERs) belong to the nuclear receptor superfamily, acting as ligand-inducible transcription factors (Hall et al, 2001).

Indeed, ER expression is regulated by a c-Src/PKC-dependent mechanism involving osteoblast differentiation, with an increased responsiveness to estrogens in mature osteoblasts (Fig.5) (Longo et al., 2004). Estrogens are also responsible for an anti-apoptotic effect on osteoblasts, which is due to a rapid and sequential phosphorylation of the c-Src, Shc and ERK1/2 kinases. The c-Src/Shc/ERK signalling cascade rapidly phosphorylates the transcription factors Elk1, CREB and C/EBP $\beta$ with a mechanism that is retained when the receptor is localized outside the nucleus (Kousteni et al, 2003).

Beside the estrogen-mediated effect, other extracellular stimuli, such as mitogens and changes in the mechanical stress, are responsible of c-Src activation and of the downstream cascade involving the MAPK signalling. In this circumstance, the transcriptional target is the AP-1 complex, a heterodimer composed of members of the c-Fos, c-Jun, and activating transcription factor (ATF) families (Hess et al, 2004), which is an important regulator of bone development and homeostasis (Wagner \& Eferl, 2005).

Of special interest in the regulation of c-Src activation and activity is the role of caveolae. They are small bulb-shaped invaginations located close to the cell surface representing specialized domains of the plasma membrane (Severs, 1988). Caveolin, a 21-24-kDa integral membrane protein, is a major structural and regulatory component of caveolae membranes (Rothberg et al., 1992). Several data suggest that caveolin may act as a scaffolding protein 


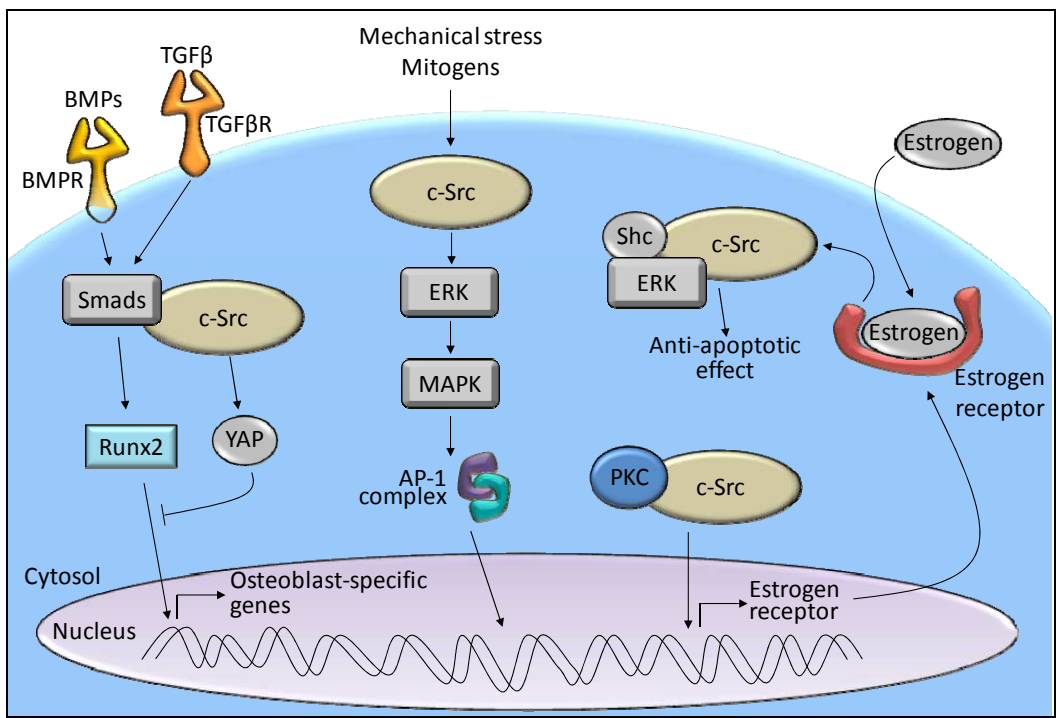

Fig. 5. c-Src involvement in osteoblast differentiation.

TGF $\beta$ /BMP signals, mechanical stress, mitogens and estrogen modulate c-Src activity and osteoblast differentiation.

within caveolae membranes, since both the N-terminal and C-terminal domains of caveolin face the cytoplasm (Dupree et al., 1993). Caveolin interacts with cytoplasmic signalling molecules including trimeric G proteins, Src family tyrosine kinases, and Ras-related GTPases. Thus, caveolin may serve as an oligomeric docking site for organizing and concentrating inactive signalling molecules within the caveolae membranes (Sargiacomo et al, 1995). Modification and/or inactivation of caveolin may be a common feature of the transformed phenotype. Caveolin can be phosphorylated by c-Src at Tyr14, an event that induces caveolar internalization by reorganizing the actin cytoskeleton (mediated by dynamin and PKC) (Mayor \& Pagano, 2007).

On the other hand, caveolin has a role in regulating c-Src activation, since its interaction with c-Src, as well as with the other components of the SFKs, leads to the inhibition of autophosphorylation of these kinases, thus holding these molecules in the inactive conformation (Li et al, 1996).

Recently, we demonstrated that in osteoblasts c-Src regulates interleukin (IL)-6 and insulin-like growth factor binding protein (IGFBP)-5 expression (Peruzzi et al, 2012). More in details, c-Src controls IL-6 expression acting on STAT3, which is a downstream component of the IL-6 pathway and a transcription factor for IL-6 itself. At the same time, IL-6 stimulates the expression of IGFBP5 which, in turn, acts in an autocrine manner on osteoblasts inducing the c-Src activating-phosphorylation and inhibiting further osteoblast differentiation. On the other hand, in mature osteoblasts c-Src is barely expressed and therefore this loop is inactive, although IGFBP5 is still expressed under the control of Runx2. In this context, IGFBP5 has been observed to enhance osteoclast formation and bone resorption, thus unveiling its new role in the coupling between osteoblast and osteoclast activities (Peruzzi et al, 2012). 


\section{4. c-Src in cancer-related bone diseases}

When deregulated, c-Src has the potential to participate in cancer pathogenesis and progression (Rucci et al, 2008). High levels of c-Src activity are found in numerous epithelial cancers, including colon and breast carcinomas (reviewed in Tsygankov \& Shore, 2004), and a correlation between c-Src activity and the degree of tumour malignancy has been described (Aligayer et al, 2002). Among several mechanisms proposed for increased c-Src activity in cancer, mutations resulting in constitutive activation of the kinase domain of the protein have been found in a subset of human cancers (Irby et al, 1999). However, it is thought that rather than being a transforming agent on its own, c-Src is a pivotal regulator of a number of signalling cascades associated with tumour development and progression, including the JAK/STAT pathway (Silva, 2004) and the EGFR family member pathways (Biscardi et al, 2000). Indeed, increased c-Src activity upregulates these signals, leading to increased cell growth, migration and invasion.

Because of the central role of c-Src in both bone metabolism and tumourigenesis, c-Src signalling may be of particular importance in patients with cancer-related bone diseases. Therefore, in this section the role of c-Src in bone malignancies such as osteosarcoma and bone metastases will be elucidated.

Osteosarcoma is the most common and most often fatal primary malignant bone tumour, especially affecting children, adolescents and young adults (Raymond et al, 2002). It is a highly aggressive tumour that metastasizes primarily to the lung, with a consequent very poor prognosis (Shanley \& Mulligan, 1991). Osteosarcoma arises from primitive transformed cells that exhibit osteoblastic features and produce malignant osteoid (Kansara \& Thomas, 2007). Among the factors involved in the progression of this pathology, c-Src has been described as a mediator of tumour cell invasive features. Caveolin- 1 downregulation has been proposed to function as a permissive mechanism by which c-Src signalling is activated, enabling osteosarcoma cells to become metastatic and invade the neighboring tissues (Cantiani et al, 2007).

Bone represents the principal site of relapse of many cancers, especially prostate and breast carcinomas. In the latter, skeletal metastases are osteolytic in nature, with a resulting bone destruction mediated by an exaggerated osteoclast activity. Tumour cells colonizing the bone produce factors that stimulate osteoclast formation, with a consequent increase of bone resorption. This leads to the release of growth factors normally stored in the bone matrix, which in turn stimulate tumour cell proliferation and survival. This mutual enhancement of tumour cell and osteoclast activities is termed "vicious cycle", which progressively increases both bone destruction and tumour burder (Weilbaecher et al, 2011). c-Src plays a role in the context of bone metastases. In fact, MDA-MB-231 breast cancer cells overexpressing a kinase dead dominant negative c-Src were found to form far less osteolytic metastases in immunocompromised mice than their wild-type counterpart (Myuoi et al, 2003; Rucci et al, 2006). Recent data demonstrate that c-Src is crucial for breast cancer cell growth in the bone marrow since it mediates AKT regulation and tumour cell survival in response to chemokine (C-X-C motif) ligand 12 CXCL12, thus confering resistance to the pro-apoptotic member of the tumour necrosis factor family, TRAIL (Zhang et al, 2009). 


\section{5. c-Src as pharmacological target in bone metastases}

Several compounds have been tested in pre-clinical studies in vitro and in vivo to inhibit c-Src activity and reduce the incidence of metastases. In an model of experimentally induced breast cancer metastases, the pyrrolo-[2,3-d]pyrimidine c-Src inhibitor, CGP76030, proved effective at inhibiting the incidence of relapse in bone and visceral organs, thus improving mice survival. CGP76030 was observed to have potent antiosteoclastic and anti-tumoral effects (Recchia et al, 2004; Rucci et al, 2006), explaining its in vivo effects on both fronts.

The efficacy of c-Src inhibitors in the treatment of breast cancer-induced bone metastases was strengthened by recent data showing that c-Src is a key signalling molecule for the growth of antiestrogen-resistant tumour cells. Indeed, it has been demonstrated that the expression of a constitutively active c-Src attenuated the sensitivity of MCF7 breast cancer cells to tamoxifen (Morgan et al, 2009). In the same cell line the synergistic interaction between ER, EGF receptor and c-Src enhanced tumour cell responsiveness to mitogenic stimuli, allowing their survival also in the presence of tamoxifen (Yue et al, 2007).

Another compound employed in preclinical studies is Dasatinib, a potent inhibitor of SFKs, which proved effective at inhibiting breast cancer cell growth, with a synergic effect when used in combination with chemotherapeutics (Nautiyal et al, 2009), while in mice inoculated with a triple-negative (for ER, progesterone receptor and Her2/neu expression) breast cancer cell line it prevented the formation of osteolytic metastases (Zhang et al, 2009).

Based on this body of evidence, clinical studies have recently been started using sarcatinib, which is a dual c-Src/Abl inhibitor. In a phase I study performed on patients with solid tumours, sarcatinib decreased the levels of bone resorption markers (Baselga et al, 2010). Sarcatinib is currently being tested in phase II clinical studies in patients with breast cancer bone metastases. Another dual c-Src/Abl inhibitor in clinical development with similar properties is Bosutinib.

\section{Conclusions}

c-Src is a non receptor tyrosine kinase ubiquitously expressed and involved in the regulation of many cellular functions, such as adhesion, growth, migration and survival. Indeed, its activity increases in response to several signals, especially downstream of growth factor and cytokine receptors, integrin receptors and G-coupled receptors. The proto-oncogene nature of c-Src is also well known, so that its aberrant activation is involved in the development and progression of many human cancers.

c-Src plays an unique role in bone metabolism, regulating the activity of both the boneresorbing osteoclasts and the bone-forming osteoblasts. The interest on c-Src within the bone metabolism derived from the pioneer work of Soriano et al. (1991), who demonstrated that, despite the ubiquitous expression of c-Src, knock-out mice showed only a bone phenotype. This molecule is currently thought to be a suitable pharmacological target for bone metastases. Clinical studies are currently in progress to establish the efficacy of c-Src inhibitors as therapeutic agents in humans. 


\section{Acknowledgements}

The original work was supported by a grant from the "Associazione Italiana per la Ricerca sul Cancro" (AIRC) to AT, and a grant from the European Calcified Tissue Society to BP. BP is recipient of the "Helga Baden" Fellowship provided by the "Fondazione Italiana per la Ricerca sul Cancro".

\section{References}

Akhand, AA., Pu, M., Senga, T., Kato, M., Suzuki, H., Miyata, T., Hamaguchi, M. \& Nakashima, I. (1999). Nitric oxide controls src kinase activity through a sulfhydryl group modification-mediated Tyr-527- independent and Tyr-416-linked mechanism, Journal of Biological Chemistry, Vol.274, No.36, (September 1999), pp. 25821-25826, ISSN 0021-9258

Aligayer, H., Boyd, DD., Heiss, MM., Abdalla, EK., Curley, SA. \& Gallick, GE. (2002). Activation of Src kinase in primary colorectal carcinoma: an indicator of poor clinical prognosis. Cancer, Vol.94, No.2, (January 2002), pp. 344-51, ISSN 0008-543X

Alvarez RH, Kantarjian HM, and Cortes JE. The role of Src in solid and hematologic malignancies: development of new-generation Src inhibitors. Cancer 107, 1918-1929. (2006) ISSN 0008-543X.

Arbet-Engels, C., Tartare-Deckert, S. \& Eckhart, W. (1999). C-terminal Src kinase associates with ligand-stimulated insulin-like growth factor-I receptor. Journal of Biological Chemistry, Vol.274, No. 9, (February 1999), pp. 5422-5428, ISSN 0021-9258

Arthur, W T. \& Burridge, K. (2001). RhoA inactivation by p190RhoGAP regulates cell spreading and migration by promoting membrane protrusion and polarity. Molecular biology of the cell, Vol.12, No. 9, (September 2001), pp. 2711-2720, ISSN 1059-1524

Baron, R. (1993). Cellular and molecular biology of the osteoclast, In: Cellular and Molecular Biology of Bone, Noda, M., Academic Press, ISBN 0-12-520225-3, San Diego

Baron, R. \& Horne, WC. (2005). Regulation of osteoclast activity, In: Topics in Bone Biology, Vol. 2, Bronner, F., Farach-Carson, MC. \& Rubin, J., Springer-Verlag, ISBN 9812562095, London

Baselga, J., Cervantes, A., Martinelli, E., Chirivella, I., Hoekman, K., Hurwitz, HI., Jodnell, DI., Hamberg, P., Casado, E., Elvin, P., Swazland, A., Iacone, R. \& Tabernero, J. (2010). Phase Isafety, pharmacokinetics and inhibition of SRC activity study of sarcatinib in patients with solid tumors. Clinical cancer research, Vol.16, No.19, (October 2010), pp. 4876-4883, ISSN 1078-0432

Behrens, J., Mareel, MM., Van Roy, FM. \& Birchmeier, W. (1989). Dissecting tumor cell invasion: epithelial cells acquire invasive properties after the loss of uvomorulinmediated cell-cell adhesion. Journal of Cell Biology, Vol.108, No.6, (June 1989), pp. 2435-2447, ISSN 0021-9525

Biscardi, JS., Ishizawar, RC., Silva, CM. \& Parsons, SJ. (2000). Tyrosine kinase signalling in breast cancer: epidermal growth factor receptor and c-Src interactions in breast cancer. Breast Cancer Research, Vol.2, No.3, (March 2000), pp. 203-210, ISSN 14655411

Bowman, T., Broome, MA., Sinibaldi, D., Wharton, W., Pledger, WJ., Sedivy, JM., Irby, R., Yeatman, T., Courtneidge, SA. \& Jove, R. (2001). Stat3-mediated Myc expression is 
required for Src transformation and PDGF-induced mitogenesis. Proceedings of the National Academy of Sciences of the United States of America, Vol.98, No.13, (June 2001), pp. 7319-7324, ISSN 0027-8424

Boyce, BF., Yoneda, T., Lowe, C., Soriano, P. \& Mundy, GR. (1992). Requirement of pp60csrc expression for osteoclasts to form ruffled borders and resorb bone in mice. Journal of clinical investigation, Vol.90, No.4, (October 1992), pp. 1622-1627, ISSN 0021-9738

Brown, MT. \& Cooper, JA. (1996). Regulation, substrates and functions of src. Biochimica et biophysica acta, Vol.1287, No.2-3, (June 1996), pp. 121-149, ISSN 0006-3002

Brugge, JS. \& Erikson, RL. (1977). Identification of a transformation-specific antigen induced by an avian sarcoma virus. Nature, Vol.269, No.5626, (September 1977), pp. 346348, ISSN 0028-0836

Brunton, VG., MacPherson, IR. \& Frame, MC. (2004). Cell adhesion receptors, tyrosine kinases and actin modulators: a complex three-way circuitry. Biochimica et biophysica acta, Vol. 1692, No.2-3, (July 2004), pp. 121-144, ISSN 0006-3002

Buccione, R., Orth, JD. \& McNiven, MA. (2004). Foot and mouth: podosomes, invadopodia and circular dorsal ruffles. Nature reviews. Molecular cell biology, Vol.5, No.8, (August 2004), pp. 647-657, ISSN 1471-0072

Cantiani, L., Manara, MC., Zucchini, C., De Sanctis, P., Zuntini, M., Valvassori, L., Serra, M., Olivero, M., Di Renzo, MF., Colombo, MP., Picci, P. \& Scotlandi, K. (2007). Caveolin-1 reduces osteosarcoma metastases by inhibiting c-Src activity and met signaling. Cancer Research, Vol.67, No.16, (August 2007), pp. 7675-7685, ISSN 00085472

Cartwright, CA., Eckhart, W., Simon, S. \& Kaplan, PL. (1987). Cell transformation by pp60csrc mutated in the carboxyterminal regulatory domain. Cell Vol.49, No.1, (April 1987), pp. 83-91, ISSN 0092-8674

Collett, MS., Brugge, JS. \& Erikson, RL. (1978). Characterization of a normal avian cell protein related to the avian sarcoma virus transforming gene product. Cell. Vol.15, No.4, (December 1978), pp. 1363-1369, ISSN 0092-8674

Cooper, JA. \& King, CS. (1986). Dephosphorylation or antibody binding to the carboxy terminus stimulates pp60c-src. Molecular and cellular biology, Vol.6, No.12, (December 1986), pp. 4467-4477, ISSN 0270-7306

Courtneidge, SA., Dhand, R., Pilat, D., Twamley, GM., Waterfield, MD. \& Roussel, MF. (1993). Activation of Src family kinases by colony stimulating factor-1, and their association with its receptor. EMBO Journal, Vol.12, No.3, (March 1993), pp. 943950, ISSN 0261-4189

Coxon, FP. \& Taylor, A. (2008). Vesicular trafficking in osteoclasts. Seminars in cell $\mathcal{E}$ developmental biology, Vol.19, No.5, (October 2008), pp. 424-433, ISSN 1084-9521

Datta, A., Huber, F. \& Boettiger, D. (2002). Phosphorylation of beta3 integrin controls ligand binding strength. The Journal of biological chemistry. Vol.277, No.6, (February 2002), pp. 3943-3949, ISSN 0021-9258

De Mali, KA., Godwin, SL., Soltoff, SP. \& Kazlauskas, A. (1999). Multiple roles for Src in a PDGF-stimulated cell. Experimental cell research, Vol.253, No.1, (November 1999), pp. 271-279, ISSN 0014-4827

Destaing, O., Saltel, F., Geminard, JC. \& Jurdic, BF. (2003). Podosomes display actin turnover and dynamic self-organization in osteoclasts expressing actin-green fluorescent 
protein. Molecular biology of the cell, Vol.14, No.2, (February 2003), pp. 407-416, ISSN 1059-1524

Duesberg, PH. \& Vogt, PK. (1970). Differences between the ribonucleic acids of transforming and nontransforming avian tumor viruses. Proceedings of the National Academy of Sciences of the United States of America, Vol.67, No.4, (December 1970), pp. 16731680, ISSN 0027-8424

Duong, LT. \& Rodan, GA. (2000). PYK2 is an adhesion kinase in macrophages, localized in podosomes and activated by beta(2)-integrin ligation. Cell motility and the cytoskeleton, Vol.47, No.3, (November 2000), pp.174-88, ISSN 0886-1544

Dupree, P., Parton, RG., Raposo, G., Kurzchalia, TV. \& Simons K. (1993). Caveolae and sorting in the trans-Golgi network of epithelial cells. The EMBO journal, Vol.12, No.4, (April 1993), pp. 1597-1605, ISSN 0261-4189

Faccio, R., Novack, DV., Zallone, A., Ross, FP. \& Teitelbaum, SL. (2003). Dynamic changes in the osteoclast cytoskeleton in response to growth factors and cell attachment are controlled by beta3 integrin. The Journal of cell biology, Vol.162, No.3, (August 2003), pp. 499-509, ISSN 0021-9525

Faccio, R., Teitelbaum, SL., Fujikawa, K., Chappel, J., Zallone, A., Tybulewicz, VL., Ross, FP. \& Swat, W. (2005). Vav3 regulates osteoclast function and bone mass. Nature medicine, Vol.11, No.3, (March 2005), pp. 284-290, ISSN 1078-8956

Fukuda, A., Hikita, A., Wakeyama, H., Akiyama, T., Oda, H., Nakamura, K. \& Tanaka, S. (2005). Regulation of osteoclast apoptosis and motility by small GTPase binding protein Rac1. Journal of bone and mineral research, Vol.20, No.12, (December 2005), pp. 2245-2253, ISSN 0884-0431

Gianni, D., Taulet, N., DerMardirossian, C. \& Bokoch, GM. (2010). c-Src-mediated phosphorylation of NoxA1 and Tks4 induces the reactive oxygen species (ROS)dependent formation of functional invadopodia in human colon cancer cells. Molecular biology of the cell, Vol.21, No.23, (December 2010), pp. 4287-4298, ISSN 1059-1524

Giannoni, E., Buricchi, F., Raugei, G., Ramponi, G. \& Chiarugi, P. (2005). Intracellular reactive oxygen species activate Src tyrosine kinase during cell adhesion and anchorage-dependent cell growth. Molecular biology of the cell Vol.25, No.15, (August 2005), pp. 6391-6403, ISSN 1059-1524

Guarino, M. (2010). Src signaling in cancer invasion. Journal of cellular physiology, Vol.223, No.1, (April 2010), pp. 14-26, ISSN 0021-9541

Hall, JM., Couse, JF. \& Korach, KS. (2001). The multifaceted mechanisms of estradiol and estrogen receptor signaling. Journal of Biological Chemistry, Vol.276, No.40, (October 2001), pp. 36869-36872, ISSN 0021-9258

Hanai, J., Chen, LF., Kanno, T., Ohtani-Fujita, N., Kim, WY., Guo, WH., Imamura, T., Ishidou, Y., Fukuchi, M., Shi, MJ., Stavnezer, J., Kawabata, M., Miyazono, K. \& Ito, Y. (1999). Interaction and functional cooperation of PEBP2/CBF with Smads. Synergistic induction of the immunoglobulin germline Calpha promoter. Journal of Biological Chemistry, Vol.274, No.44, (October 1999), pp. 31577-31582, ISSN 00219258

Hess, J., Angel, P. \& Schorpp-Kistner, M. (2004). AP-1 subunits: quarrel and harmony among siblings. Journal of cell science, Vol.117, Pt.25, (December 2004), pp. 59655973, ISSN 0021-9533 
Horton, MA. (1997). The aVß3 integrins 'vitronectin receptor'. The international journal of biochemistry \& cell biology, Vol.29, No.5, (May 1997), pp. 721-725, ISSN 1357-2725

Horton, MA. \& Rodan, GA. (1996). Integrins as therapeutic targets in bone disease. In: Adhesion Receptors as Therapeutic Targets, Horton, MA., CRC Press Inc., ISBN 9780849376559, Boca Raton

Hunter, T. \& Sefton, BM. (1980) Transforming gene product of Rous sarcoma virus phosphorylates tyrosine. Proceedings of the National Academy of Sciences of the United States of America, Vol.77, No.3, (March 1980), pp. 1311-1315, ISSN 0027-8424

Irby, RB. \& Yeatman, TJ. (2002). Increased Src activity disrupts cadherin/catenin-mediated homotypic adhesion in human colon cancer and transformed rodent cells. Cancer Research, Vol.62, No.9, (May 2002), pp. 2669-2674, ISSN 0008-5472

Irby, RB., Mao, W., Coppola, D., Kang, J., Loubeau, JM., Trudeau, W., Karl, R., Fujita, DJ., Jove, R. \& Yeatman, TJ. (1999). Activating SRC mutation in a subset of advanced human colon cancers. Nature Genetics, Vol.21, No.2, (February 1999), pp. 187-190, ISSN 1061-4036

Irby, RB. \& Yeatman, TJ. (2000) Role of Src expression and activation in human cancer. Oncogene, Vol.19, No.49, (November 2000), pp. 5636-5642, ISSN 0950-9232

Jiang, Y., Jiang, Y., Jahagirdar, BN., Reinhardt, RL., Schwartz, RE., Keene, CD., OrtizGonzalez, XR., Reyes, M., Lenvik, T., Lund, T., Blackstad, M., Du, J., Aldrich, S., Lisberg, A., Low, WC., Largaespada, DA. \& Verfaillie, CM. (2002). Pluripotency of mesenchymal stem cells derived from adult marrow. Nature, Vol.418, No.6893, (July 2002), pp. 41-49, ISSN 0028-0836

Jove, R. \& Hanafusa, H. (1987). Cell transformation by the viral src oncogene. Annual review of cell biology, Vol.3, (November 1987), pp. 31-56, ISSN 0743-4634

Jung, EJ. \& Kim, CW. (2002). Interaction between chicken protein tyrosine phosphatase 1 (CPTP1)-like rat protein phosphatase 1 (PTP1) and p60(v-src) in v-src transformed Rat-1 fibroblasts. Experimental \& molecular medicine, Vol.34, No.6, (December 2002), pp. 476-480, ISSN 1226-3613

Kamei, T. Machida K, Nimura Y, Senga T, Yamada I, Yoshii S, Matsuda S, Hamaguchi M. (2000). C-Cbl protein in human cancer tissues is frequently tyrosine phosphorylated in a tumor-specific manner. International journal of oncology, Vol.17, No.2, (August 2000), pp. 335-339, ISSN 1019-6439

Kansara, M. \& Thomas, DM. (2007). Molecular pathogenesis of osteosarcoma. DNA and cell biology, Vol.26, No.1, (January 2007), pp. 1-18, ISSN 1044-5498

Kim, M., Tezuka, T., Tanaka, K. \& Yamamoto, T. (2004). Cbl-c suppresses v-Src-induced transformation through ubiquitin-dependent protein degradation. Oncogene, Vol.23, No.9, (March 2004), pp. 1645-1655, ISSN 0950-9232

Kmiecik, TE. \& Shalloway, D. (1987). Activation and suppression of pp60c-src transforming ability by mutation of its primary sites of tyrosine phosphorylation. Cell, Vol.49, No.1, (April 1987), pp. 65-73, ISSN 0092-8674

Koegl, M., Zlatkine, P., Ley, SC., Courtneidge, SA. \& Magee, AI. (1994). Palmitoylation of multiple Src-family kinases at a homologous N-terminal motif. The Biochemical journal, Vol.303, Pt.3, (November 1994), pp. 749-753, ISSN 0264-6021

Komori, T., Yagi, H., Nomura, S., Yamaguchi, A., Sasaki, K., Deguchi, K., Shimizu, Y., Bronson, RT., Gao, YH., Inada, M., Sato, M., Okamoto, R., Kitamura, Y., Yoshiki, S. \& Kishimoto, T. (1997). Targeted disruption of Cbfa1 results in a complete lack of 
bone formation owing to maturational arrest of osteoblasts. Cell, Vol.89, No.5, (May 1997), pp. 755-764, ISSN 0092-8674

Kousteni, S., Han, L., Chen, JR., Almeida, M., Plotkin, LI., Bellido, T. \& Manolagas, SC. (2003). Kinase-mediated regulation of common transcription factors accounts for the bone-protective effects of sex steroids. The Journal of clinical investigation, Vol.111, No.11, (June 2003), pp. 1651-1664, ISSN 0021-9738

Landgren, E., Blume-Jensen, P., Courtneidge, SA. \& Claesson-Welsh, L. (1995). Fibroblast growth factor receptor-1 regulation of Src family kinases. Oncogene, Vol.10, No.10, (May 1995), pp. 2027-2035, ISSN 0950-9232

Li, S., Couet, J. \& Lisanti, MP. (1996). Src tyrosine kinases, Galpha subunits, and H-Ras share a common membrane-anchored scaffolding protein, caveolin. Caveolin binding negatively regulates the auto-activation of Src tyrosine kinases. The Journal of biological chemistry, Vol.271, No.46, (November 1996), pp. 29182-29190, ISSN 00219258

Linder, S. \& Aepfelbacher, M. (2003). Podosomes: adhesion hot-spots of invasive cells. Trends in cell biology, Vol.13, No.7, (July 2003), pp. 376-385, ISSN 0962-8924

Longo, M., Brama, M., Marino, M., Bernardini, S., Korach, KS., Wetsel, WC., Scandurra, R., Faraggiana, T., Spera, G., Baron, R., Teti, A. \& Migliaccio, S. (2004). Interaction of estrogen receptor alpha with protein kinase $C$ alpha and c-Src in osteoblasts during differentiation. Bone, Vol.34, No.1, (January 2004), pp. 100-111, ISSN 8756-3282

Lowe, C., Yoneda, T., Boyce, BF., Chen, H., Mundy, GR. \& Soriano, P. (1993). Osteopetrosis in Src deficient mice is due to an autonomous defect of osteoclasts. Proceedings of the National Academy of Sciences of the United States of America, Vol.90, No.10, (May 1993), pp. 4485-4489, ISSN 0027-8424

Lowell, CA., Niwa, M., Soriano, P. \& Varmus, HE. (1996). Deficiency of the Hck and Src tyrosine kinases results in extreme levels of extramedullary hematopoiesis. Blood, Vol.87, No.5, (May 1996), pp. 1780-1792, ISSN 0006-4971

Manolagas, SC., Kousteni, S. \& Jilka, RL. (2002). Sex steroids and bone. Recent Progress in Hormone Research, Vol.57, (2002), pp. 385-409, ISSN 0079-9963

Mao, W., Irby, R., Coppola, D., Fu, L., Wloch, M., Turner, J., Yu, H., Garcia, R., Jove, R. \& Yeatman, TJ. (1997). Activation of c-Src by receptor tyrosine kinases in human colon cancer cells with high metastatic potential. Oncogene, Vol.15, No.25, (December 1997), pp. 3083-3090, ISSN 0950-9232

Marchisio, PC., Cirillo, D., Naldini, L., Primavera, MV., Teti, A. \& Zambonin-Zallone, A. (1984). Cell-substratum interaction of cultured avian osteoclasts is mediated by specific adhesion structures. The Journal of cell biology, Vol.99, No.5, (November 1984), pp. 1696-1705, ISSN 0021-9525

Marchisio, PC., Cirillo, D., Teti, A., Zambonin-Zallone, A. \& Tarone, G. (1987). Rous sarcoma virus transformed fibroblasts and cells of monocytic origin display a peculiar dotlike organization of cytoskeletal proteins involved in microfilament-membrane interactions. Experimental cell research, Vol.169, No.1, (March 1987), pp. 202-214, ISSN 0014-4827

Martin, GS. (1970). Rous sarcoma virus: a function required for the maintenance of the transformed state. Nature, Vol.227, No.5262, (September 1970), pp. 1021-1023, ISSN 0028-0836 
Marzia, M., Sims, NA., Voit, S., Migliaccio, S., Taranta, A., Bernardini, S., Faraggiana, T., Yoneda, T., Mundy, GR., Boyce, BF., Baron, R. \& Teti, A. (2000). Decreased c-Src expression enhances osteoblast differentiation and bone formation. The Journal of cell biology, Vol. 151, No.2, (October 2000), pp. 311-320, ISSN 0021-9525

Mayer, BJ., Jackson, PK. \& Baltimore, D. (1991). The noncatalytic src homology region 2 segment of abl tyrosine kinase binds to tyrosine-phosphorylated cellular proteins with high affinity. Proceedings of the National Academy of Sciences of the United States of America, Vol.88, No.2, (January 1991), pp. 627-631, ISSN 0027-8424

Mayer, BJ. \& Baltimore, D. (1993). Signalling through SH2 and SH3 domains. Trends in cell biology, Vol.3, No.1, (January 1993), pp. 8-13, ISSN 0962-8924

Mayor, S. \& Pagano, RE. (2007). Pathways of clathrin independent endocytosis. Nature reviews. Molecular cell biology, Vol.8, No.8, (August 2007), pp. 603-612, ISSN 14710072

McLean, GW., Carragher, NO., Avizienyte, E., Evans, J., Brunton, VG. \& Frame, MC. (2005). The role of focal-adhesion kinase in cancer-a new therapeutic opportunity. Nature reviews. Cancer, Vol.5, No.7, (July 2005), pp. 505-515, ISSN 1474-175X

Miyamoto, S., Akiyama, SK. \& Yamada, KM. (1995). Synergistic roles for receptor occupancy and aggregation in integrin transmembrane function. Science, Vol.267, No.5199, (February 1995), pp. 883-885, ISSN 0036-8075

Miyamoto, S., Teramoto, H., Gutkind, JS. \& Yamada, KM. (1996). Integrins can collaborate with growth factors for phosphorylation of receptor tyrosine kinases and MAP kinase activation: Roles of integrin aggregation and occupancy of receptors. The Journal of cell biology, Vol.135, No.6 Pt.1, (December 1996), pp. 1633-1642, ISSN 00219525

Miyazaki, T., Neff, L., Tanaka, S., Horne, WC. \& Baron, R. (2003). Regulation of cytochrome c oxidase activity by c-Src in osteoclasts. The Journal of cell biology, Vol.160, No.5, (March 2003), pp. 709-718, ISSN 0021-9525

Miyazaki, T., Sanjay, A., Neff, L., Tanaka, S., Horne, WC. \& Baron, R. (2004). Src kinase activity is essential for osteoclast function. The Journal of biological chemistry, Vol.279, No.17, (April 2004), pp. 17660-17666, ISSN 0021-9258

Miyazaki, T., Tanaka, S., Sanjay, A. \& Baron, R. (2006). The role of c-Src kinase in the regulation of osteoclast function. Modern rheumatology, Vol.16, No.2, (2006), pp. 6874, ISSN 1439-7595

Mocsai, A., Humphrey, MB., Van Ziffle, JA., Hu, Y., Burghardt, A., Spusta, SC., Majumdar, S., Lanier, LL., Lowell, CA., Nakamura, MC. (2004). The immunomodulatory adapter proteins DAP12 and $\mathrm{Fc}$ receptor gamma-chain (FCR gamma) regulate development of functional osteoclasts through the Syk tyrosine kinase. Proceedings of the national academy of science USA, Vol. 101, No.16, (April 2004) pp.6158-6163

Morgan, L., Gee, J., Pumford, S., Farrow, L., Finlay, P., Robertson, J., Ellis, I., Kawakatsu, H., Nicholson, R. \& Hiscox, S. (2009). Elevated Src kinase activity attenuates Tamoxifen response in vitro and is associated with poor prognosis clinically. Cancer biology $\mathcal{E}$ therapy, Vol.8, No.16, (August 2009), pp. 1550-1558, ISSN 1538-4047

Myuoi, A., Nishimura, P., Williams, PJ., Tamura, D., Michigami, T., Mundy, GR. \& Yoneda, T. (2003). c-Src tyrosine kinase activity is associated with tumor colonization in bone and lung in an animal model of human breast cancer bone metastasis. Cancer research, Vol.63, No.16, (August 2003), pp. 5028-5033, ISSN 0008-5472 
Nakamura, I., Duong, le T., Rodan, SB. \& Rodan, GA. (2007). Involvement of alpha(v)beta3 integrins in osteoclast function. Journal of bone and mineral metabolism, Vol.25, No.6, (October 2007), pp. 337-344, ISSN 0914-8779

Nam, JS., Ino, Y., Sakamoto, M. \& Hirohashi, S. (2002). Src family kinase inhibitor PP2 restores the E-cadherin/catenin cell adhesion system in human cancer cells and reduces cancer metastasis. Clinical cancer research, Vol.8, No.7, (July 2002), pp. 24302436, ISSN 1078-0432

Nautiyal, J., Majumder, P., Patel, BB., Lee, FY. \& Majumdar, AP. (2009). Src inhibitor dasatinib inhibits growth of breast cancer cells by modulating EGFR signaling. Cancer letters, Vol283, No.2, (October 2009), pp. 143-151, ISSN 0304-3835

Okada, M. \& Nakagawa, H. (1989). A protein tyrosine kinase involved in regulation of pp60c-src function. The Journal of biological chemistry, Vol.264, No.35, (December 1989), pp. 20886-20893, ISSN 0021-9258

Oppermann, H., Levinson, AD., Varmus, HE., Levintow, L. \& Bishop, JM. (1979). Uninfected vertebrate cells contain a protein that is closely related to the product of the avian sarcoma virus transforming gene (src). Proceedings of the National Academy of Sciences of the United States of America, Vol.76, No.4, (April 1979), pp. 1804-1808, ISSN 00278424

Pawson, T. (1995). Protein modules and signalling networks. Nature, Vol.373, No.6515, (February 1995), pp. 573-580, ISSN 0028-0836

Peruzzi B, Cappariello A, Del Fattore A, Rucci N, De Benedetti F, Teti A. (2012) c-Src and IL6 inhibit osteoblast differentiation and integrate IGFBP5 signalling. Nature Communications, Vol. 3, (January 2012) article number 630. ISSN 2041-1723, doi: $10.1038 /$ ncomms1651.

Peruzzi, B. \& Teti, A. (2011). The Physiology and Pathophysiology of the Osteoclast, Clinical Reviews in Bone and Mineral Metabolism, ISSN 1534-8644, DOI: 10.1007/s12018-0119086-6

Piwnica-Worms, H., Saunders, KB., Roberts, TM., Smith, AE. \& Cheng, SH. (1987). Tyrosine phosphorylation regulates the biochemical and biological properties of pp60c-src. Cell, Vol.49, No.1, (April 1987), pp. 75-82, ISSN 0092-8674

Playford, MP. \& Schaller, MD. (2004). The interplay between Src and integrins in normal and tumor biology. Oncogene, Vol.23, No.48, (October 2004), pp. 7928-7946, ISSN 0950-9232

Raymond, AK., Ayala, AG. \& Knuutila, S. (2002). Conventional osteosarcoma. In: World Health Organization classification of tumors, Fletcher, CDM., Unni, KK. \& Mertens, F., IARC Press, ISBN 928322413 2, Lyon:, 2002. p. 264-70.

Recchia, I., Rucci, N., Funari, A., Migliaccio, S., Taranta, A., Longo, M., Kneissel, M., Susa, M., Fabbro, D. \& Teti, A. (2004). Reduction of c-Src activity by substituted 5,7diphenyl-pyrrolo[2,3-d]-pyrimidines induces osteoclast apoptosis in vivo and in vitro. Involvement of ERK1/2 pathway. Bone, Vol.34, No.1, (January 2004), pp. 6579, ISSN 8756-3282

Ren, R., Mayer, BJ., Cicchetti, P. \& Baltimore, D. (1993). Identification of a ten amino acid proline-rich SH3 binding site. Science, Vol.259, No.5098, (February 1993), pp. 11571161, ISSN 0036-8075 
Resh, MD. (1999). Fatty acylation of proteins: new insights into membrane targeting of myristoylated and palmitoylated proteins. Biochimica et biophysica acta, Vol.1451, No.1, (August 1999), pp. 1-16, ISSN 0006-3002

Roby, KF., Son, DS., Taylor, CC., Montgomery-Rice, V., Kirchoff, J., Tang, S. \& Terranova, PF. (2005). Alterations in reproductive function in SRC tyrosine kinase knockout mice. Endocrine, Vol. 26, No.2, (March 2005), pp. 169-176, ISSN 1355-008X

Rodan, GA. \& Martin, TJ. (1981). Role of osteoblasts in hormonal control of bone resorption-a hypothesis. Calcified tissue International, Vol.33, No.4, (1981), pp. 349-351, ISSN 0171-967X

Rothberg, KG., Heuser, JE., Donzell, WC., Ying, YS., Glenney, JR. \& Anderson, RG. (1992). Caveolin, a protein component of caveolae membrane coats. Cell, Vol68, No. 4, (February 1992), pp. 673-682, ISSN 0092-8674

Rous, PA. (1911a). Transmission of a malignant new growth by means of a cell-free filtrate. Journal of the American Medical Association, Vol.56, (1911), pp. 98, ISSN 0098-7484

Rous, PA. (1911b). A sarcoma of the fowl transmissible by an agent separable from the tumor cells. The Journal of experimental medicine, Vol.13, No.4, (April 1911), pp. 397411, ISSN 0022-1007

Rubin, H. (1995). Quantitative relations between causative virus and cell in the Rous No. 1 chicken sarcoma. Virology, Vol.1, No.5, (December 1955), pp. 445-473, ISSN 00426822

Rucci, N., Recchia, I., Angelucci, A., Alamanou, M., Del Fattore, A., Fortunati, D., Susa, M., Fabbro, D., Bologna, M. \& Teti, A. (2006). Inhibition of protein kinase c-Src reduces th incidence of breast cancer metastases and increases survival in mice: implication for therapy. The Journal of pharmacology and experimental therapeutics, Vol. 318, No.1, (July 2006), pp. 161-172, ISSN 0022-3565

Rucci, N., Susa, M. \& Teti, A. (2008). Inhibition of protein kinase c-Src as a therapeutic approach for cancer and bone metastases. Anti-cancer agents in medicinal chemistry, Vol.8, No.3, (April 2008), pp. 342-349, ISSN 1871-5206

Rupp, PA. \& Little, CD. (2001). Integrins in vascular development. Circulation research, Vol.89, No.7, (September 2001), pp. 566-572, ISSN 0009-7330

Sakai, T., Jove, R., Fassler, R. \& Mosher, DF. (2001). Role of the cytoplasmic tyrosines of beta $1 \mathrm{~A}$ integrins in transformation by v-src. Proceedings of the National Academy of Sciences of the United States of America, Vol.98, No.7, (March 2001), pp. 3808-3813, ISSN 0027-8424

Sanjay, A., Houghton, A., Neff, L., DiDomenico, E., Bardelay, C., Antoine, E., Levy, J., Gailit, J., Bowtell, D., Horne, WC. \& Baron, R. (2001). Cbl associates with Pyk2 and Src to regulate Src kinase activity, alpha(v)beta(3) integrin-mediated signaling, cell adhesion, and osteoclast motility. The Journal of cell biology, Vol.152, No. 1, (January 2001), pp. 181-195, ISSN 0021-9525

Sargiacomo, M., Scherer, PE., Tang, Z., Kübler, E., Song, KS., Sanders, MC. \& Lisanti, MP. (1995). Oligomeric structure of caveolin: implications for caveolae membrane organization. Proceedings of the National Academy of Sciences of the United States of America, Vol.92, No.20, (September 1995), pp. 9407-9411, ISSN ISSN 0027-8424

Schaller, MD., Hildebrand, JD., Shannon, JD., Fox, JW., Vines, RR. \& Parsons, JT. (1994). Autophosphorylation of the focal adhesion kinase, pp125FAK, directs SH2- 
dependent binding of pp60src. Molecular and cellular biology, Vol.14, No.3, (March 1994), pp. 1680-1688, ISSN 0270-7306

Schlaepfer, DD. \& Hunter, T. (1998). Integrin signaling and tyrosine phosphorylation: Just the FAKs? Trends in cell biology, Vol.8, No.4, (April 1998), pp. 151-157, ISSN 09628924

Severs, NJ. (1988). Caveolae: static inpocketings of the plasma membrane, dynamic vesicles or plain artifact? Journal of cell science, Vol.90, Pt.3, (July 1988), pp. 341-348, ISSN 0021-9533

Shanley, DJ. \& Mulligan, ME. (1991). Osteosarcoma with isolated metastases to the pleura. Pediatric radiology, Vol.21, No.3, (1991), pp.226, ISSN 0301-0449

Silva, CM. (2004). Role of STATs as downstream signal transducers in Src family kinasemediated tumorigenesis Oncogene, Vol.23, No.48, (October 2004), pp. 8017-8023, ISSN 0950-9232

Soriano, P., Montgomery C., Geske R. \& Bradley A.. (1991). Targeted disruption of the c-src proto-oncogene leads to osteopetrosis in mice. Cell, Vol.64, No.4, (February 1991), pp. 693-702, ISSN 0092-8674

Stein, GS., van Wijnen, AJ., Stein, JL., Lian, JB., Montecino, M., Choi, JY., Zaidi, K. \& Javed, A. (2000). Intranuclear trafficking of transcription factors: implications for biological control. Journal of cell science, Vol.113, Pt.14, (July 2000), pp. 2527-2533, ISSN 0021-9533

Stein, PL., Vogel, H. \& Soriano, P. (1994). Combined deficiencies of Src, Fyn, and Yes tyrosine kinases in mutant mice. Genes $\mathcal{E}$ development, Vol.8, No.17, (September 1994), pp. 1999-2007, ISSN 0890-9369

Suda, T., Nakamura, I., Jimi, E. \& Takahashi, N. (1997). Regulation of osteoclast function. Journal of bone and mineral research, Vol.12, No.6, (June 1997), pp. 869-879, ISSN 08840431

Takeya, T. \& Hanafusa, H. (1983). Structure and sequence of the cellular gene homologous to the RSV src gene and the mechanism for generating the transforming virus. Cell, Vol.32, No.3, (March 1983), pp. 881-890, ISSN 0092-8674

Teitelbaum SL. (2007). Osteoclasts: what do they do and how do they do it? The American journal of pathology, Vol.170, No.2, (February 2007), pp. 427-435, ISSN 0002-9440

Thomas, SM. \& Brugge, JS. (1997). Cellular functions regulated by Src family kinases. Annual Review of Cell and Developmental Biology, Vol.13, (November 1997), pp. 513-609, ISSN 1081-0706

Thomas, JW., Ellis, B., Boerner, RJ., Knight, WB., White, GC.II \& Schaller, MD. (1998). SH2and SH3-mediated interactions between focal adhesion kinase and Src. The Journal of biological chemistry, Vol.273, No.1, (January 1998), pp. 577-583, ISSN 0021-9258

Tice, DA., Biscardi, JS., Nickles, AL. \& Parsons, SJ. (1999). Mechanism of biological synergy between cellular Src and epidermal growth factor receptor. Proceedings of the National Academy of Sciences of the United States of America, Vol.96, No.4, (February 1999), pp. 1415-1420, ISSN ISSN 0027-8424

Timpson, P., Jones, GE., Frame, MC. \& Brunton, VG. (2001). Coordination of cell polarization and migration by the Rho family GTPases requires Src tyrosine kinase activity. Current biology, Vol.11, No.23, (November 2001), pp. 1836-1846, ISSN 09609822 
Tsygankov, AY. \& Shore, SK. Src: regulation, role in human carcinogenesis and pharmacological inhibitors. Current pharmaceutical design, Vol.10, No.15, (2004), pp. 1745-1756, ISSN 1381-6128

van der Geer, P., Hunter, T., \& Lindberg, RA. (1994). Receptor protein-tyrosine kinases and their signal transduction pathways. Annual review of cell biology, Vol.10, (1994), pp. 251-337, ISSN 0743-4634

Wagner, EF. \& Eferl R. (2005). Fos/AP-1 proteins in bone and the immune system. Immunological reviews, Vol.208, (December 2005), pp. 126-140, ISSN 0105-2896

Wei, Y., Yang, X., Liu, Q., Wilkins, JA., \& Chapman, HA. (1999). A role for caveolin and the urokinase receptor in integrin-mediated adhesion and signaling. The Journal of cell biology, Vol.144, No.6, (March 1999), pp. 1285-1294, ISSN 0021-9525

Weilbaecher, KN., Guise, TA. \& McCauley, LK. (2011). Cancer and bone: a fatal attraction. Nature reviews. Cancer, Vol.11, No.6, (June 2011), pp. 411-425, ISSN 1474-175X

Westendorf, JJ. \& Hiebert, SW. (1999). Mammalian runt-domain proteins and their roles in hematopoiesis, osteogenesis, and leukemia. Journal of cellular biochemistry, Suppl. 32-33, (1999), pp. 51-58, ISSN 0730-2312

Wilder, RL. (2002). Integrin alpha V beta 3 as a target for treatment of rheumatoid arthritis and related rheumatic diseases. Annals of the Rheumatic Diseases, Vol.61, Suppl.2, (November 2002), pp. 96-99, ISSN 0003-4967

Winkler, DG., Park, I., Kim, T., Payne, NS., Walsh, CT., Strominger, JL. \& Shin, J. (1993). Phosphorylation of Ser-42 and Ser-59 in the N-terminal region of the tyrosine kinase p56lck. Proceedings of the National Academy of Sciences of the United States of America, Vol.90, No.11, (June 1993), pp. 5176-5180, ISSN ISSN 0027-8424

Yagi, R., Chen, LF., Shigesada, K., Murakami, Y. \& Ito, Y. (1999). A WW domain-containing yes-associated protein (YAP) is a novel transcriptional co-activator. The EMBO Journal, Vol.18, No.9, (May 1999), pp. 2551-2562, ISSN 0261-4189

Yamaguchi, H. \& Hendrickson, WA. (1996). Structural basis for activation of human lymphocyte kinase Lck upon tyrosine phosphorylation. Nature, Vol.384, No.6608, (December 1996), pp. 484-489, ISSN 0028-0836

Yeatman, TJ. (2004). A renaissance for SRC. Nature reviews. Cancer, Vol.4, No.6, (June 2004), pp. 470-480, ISSN 1474-175X

Yokouchi, M., Kondo, T., Sanjay, A., Houghton, A., Yoshimura, A., Komiya, S., Zhang, H. \& Baron, R. (2001). Src-catalyzed phosphorylation of c-Cbl leads to the interdependent ubiquitination of both proteins. The Journal of biological chemistry, Vol.276, No.37, (September 2001), pp. 35185-35193, ISSN 0021-9258

Yue, W., Fan, P., Wang, J., Li, Y. \& Santen, RJ. (2007). Mechanisms of acquired resistance to endocrine therapy in hormone-dependent breast cancer cells. The Journal of steroid biochemistry and molecular biology, Vol.106, No.1-5, (August-September 2007), pp. 102-110,, ISSN 0960-0760

Zaidi, SK., Javed, A., Choi, JY., van Wijnen, AJ., Stein, JL., Lian, JB. \& Stein, GS. (2001). A specific targeting signal directs Runx2/Cbfa1 to subnuclear domains and contributes to transactivation of the osteocalcin gene. Journal of cell science, Vol.114, Pt.17, (September 2001), pp. 3093-3102, ISSN 0021-9533

Zhang, XH., Wang, Q., Gerald, W., Hodis, CA., Norton, L., Smid, M., Foekens, JA. \& Massagué, J. (2009). Latent bone metastasis in breast cancer tied to Src-dependent survival signals. Cancer Cell, Vol.16, No.1, (July 2009), pp. 67-78, ISSN 1535-6108 
Zheng, XM., Wang, Y. \& Pallen, CJ. (1992). Cell transformation and activation of pp60c-src by overexpression of a protein tyrosine phosphatase. Nature, Vol.359, No.6393, (September 1992), pp. 336-339, ISSN 0028-0836

Zou, W., Kitaura, H., Reeve, J., Long, F., Tybulewicz, VL., Shattil, SJ., Ginsberg, MH., Ross, FP. \& Teitelbaum, SL. (2007). Syk, c-Src, the alphavbeta3 integrin, and ITAM immunoreceptors, in concert, regulate osteoclastic bone resorption. The Journal of cell biology, Vol.176, No.6, (March 2007), pp. 877-888, ISSN 0021-9525 


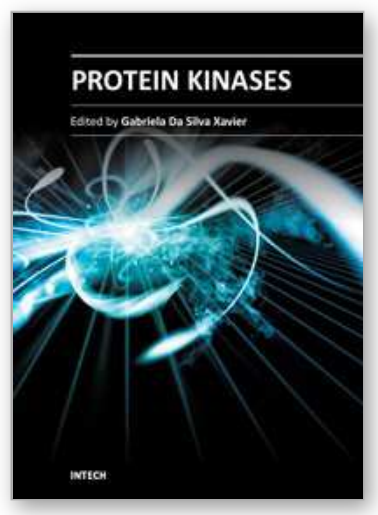

\author{
Protein Kinases \\ Edited by Dr. Gabriela Da Silva Xavier
}

ISBN 978-953-51-0640-1

Hard cover, 484 pages

Publisher InTech

Published online 05, June, 2012

Published in print edition June, 2012

Proteins are the work horses of the cell. As regulators of protein function, protein kinases are involved in the control of cellular functions via intricate signalling pathways, allowing for fine tuning of physiological functions. This book is a collaborative effort, with contribution from experts in their respective fields, reflecting the spirit of collaboration - across disciplines and borders - that exists in modern science. Here, we review the existing literature and, on occasions, provide novel data on the function of protein kinases in various systems. We also discuss the implications of these findings in the context of disease, treatment, and drug development.

\title{
How to reference
}

In order to correctly reference this scholarly work, feel free to copy and paste the following:

Barbara Peruzzi, Nadia Rucci and Anna Teti (2012). The Crucial Role of c-Src Tyrosine Kinase in Bone Metabolism, Protein Kinases, Dr. Gabriela Da Silva Xavier (Ed.), ISBN: 978-953-51-0640-1, InTech, Available from: http://www.intechopen.com/books/protein-kinases/the-crucial-role-of-c-src-tyrosine-kinase-in-bonemetabolism

\section{INTECH}

open science | open minds

\section{InTech Europe}

University Campus STeP Ri

Slavka Krautzeka 83/A

51000 Rijeka, Croatia

Phone: +385 (51) 770447

Fax: +385 (51) 686166

www.intechopen.com

\section{InTech China}

Unit 405, Office Block, Hotel Equatorial Shanghai

No.65, Yan An Road (West), Shanghai, 200040, China

中国上海市延安西路65号上海国际贵都大饭店办公楼405单元

Phone: +86-21-62489820

Fax: +86-21-62489821 
(C) 2012 The Author(s). Licensee IntechOpen. This is an open access article distributed under the terms of the Creative Commons Attribution 3.0 License, which permits unrestricted use, distribution, and reproduction in any medium, provided the original work is properly cited. 